\title{
USAHA TANI CABAI RAWIT PADA PERTANIAN LAHAN KERING DI KECAMATAN BINANGUN KABUPATEN BLITAR
}

\author{
Oleh: \\ Dian Oktavina Pratiwi' dan Suparmini ${ }^{2}$ \\ ${ }^{1}$ Program Studi Magister Kependudukan UGM \\ 2Jurusan Pendidikan Geografi Fakultas IImu Sosial UNY \\ dian.oktavina@gmail.com
}

\begin{abstract}
Abstrak
Penelitian ini merupakan penelitian studi kasus di Desa Salamrejo (SI.Rejo) dan Sumber Kembar (Sb.Kembar) dengan tujuan mengetahui: (1) kesesuaian faktor fisik dan faktor pembatas dengan syarat tumbuh tanaman; (2) faktor non fisik yang mempengaruhi usaha tani (UT); (3) pengelolaan UT pertanian lahan kering; (4) hambatan dan solusi UT; (5) perbedaan produktivitas bersih kedua daerah; 6) Hubungan antara biaya produksi dengan produktivitas bersih. Populasi sebanyak 1.283 kepala rumah tangga petani lahan kering dengan 93 sampel. Hasil: (1) Faktor fisik Sb.Kembar tidak sesuai dengan syarat tumbuh sedangkan SI.Rejo sesuai, dan terdapat beberapa faktor pembatas. (2) Sb.Kembar menggunakan modal lebih kecil dan lebih banyak tenaga kerja upah, transportasi motor lebih banyak di SI.Rejo, sedangkan alat pengolah lahan sama. (3) Sb.Kembar lebih lama mengolah lahan tetapi lebih banyak pembibitan sendiri sedangkan pemeliharaan lebih intensif di SI.Rejo. (4) Hambatan fisik lebih besar di Sb.Kembar solusinya membuat bedengan dan pupuk organik; hambatan modal lebih besar di Sb.Kembar solusinya meminjam keluarga dan menyimpan hasil panen berupa uang; hambatan serangan hama lebih besar di Sl.Rejo solusinya melakukan penyemprotan. (5) Produksi rata-rata pertahun lebih besar di SI.Rejo, demikian pula produktivitas kotor dan bersih. Biaya produksi lebih besar di Sb.Kembar (6) Hubungan biaya produksi dengan produktivitas bersih di Sb.Kembar bersifat positif sedangkan Sl.Rejo negatif.
\end{abstract}

Kata kunci: Usaha tani, cabai rawit, perbedaan produktivitas

\begin{abstract}
This research is a case study research conducted in Salamrejo (SI.Rejo) and Sumber Kembar (Sb.Kembar) Village which aims at investigating: (1) the suitability of physical and limiting factors to the condition of growing plants; (2) non-physical factors that affect farming; (3) management of agricultural farming in dry land; (4) farming problems and solutions; (5) the differences of net productivity in both regions; and (6) the relationship between production costs and net productivity. The population was 1,283 dryland farmer households and the samples were 93 households. The results are: (1) Physical factors in Sb.Kembar is not suitable with the conditions of growing plants while in SI.Rejo it is suitable, in addition there are several limiting factors. (2) Sb.Kembar uses smaller capital and has more wage labor than SI.Rejo. Moreover, there are more motorcycles for transportation in Sl.Rejo than that of Sb. Kembar, while the equipments are same in both areas. (3) Sb.Kembar cultivates the land longer and they perform their own breeding while more intensive maintenance is performed in SI.Rejo. (4) Physical constraints are greater in Sb.Kembar than $\mathrm{SI}$. Rejo and the solution is making organic beds and fertilizers; capital challenges are greater in Sb.Kembar and the solution is borrowing from the family and keeps the harvest in the form of money; the problems related to pest attacks is greater in SI.Rejo and the
\end{abstract}


solution is spraying. (5) The average annual production, as well as gross and net productivity are higher in SI.Rejo. The production cost is greater in Sb.Kembar. (6) The relationship between production cost and net productivity in Sb.Kembar is positive while Sl.Rejo is negative.

Keywords: farming, cayenne pepper, productivity difference

\section{PENDAHULUAN}

Indonesia selain sebagai negara maritime juga dikenal dengan sebutan negara agraris. Pertanian menjadi salah satu mata pencaharian terpenting bagi sebagian besar penduduk Indonesia. Pembangunan dalam sektor pertanian mencakup pertanian tanaman pangan, perkebunan, perikanan, dan peternakan. Pembangunan pertanian sub sektor pangan merupakan sektor terpenting dalam kehidupan masyarakat di perdesaan. Jenis pertanian yang diusahakan oleh penduduk Indonesia sangat beragam, seperti pertanian lahan kering dan pertanian lahan basah. Lahan kering merupakan hamparan lahan yang tidak pernah tergenang atau digenangi air pada sebagian besar waktu dalam setahun atau sepanjang waktu. Ciri utama yang menonjol di lahan kering adalah terbatasnya air, makin menurunnya produktivitas lahan, tingginya variabilitas kesuburan tanah, macam spesies tanaman yang di tanam, serta aspek sosial, ekonomi dan budaya (Suparmini dkk, 2015).

Lahan kering sebenarnya memiliki potensi yang sama dengan lahan basah. Melihat kondisi saat ini sebagian besar lahan basah (sawah) telah mengalami alih fungsi lahan dan hasil produktivitas pangan menurun drastis dari tahun-ketahun (suparmini dkk, 2015). Pemerintah mulai melirik pengembangan lahan kering sebab lahan kering memiliki potensi dan peluang yang sangat besar untuk di kembangkan di masa yang akan datang. Kondisi ini dapat di tinjau dari sifat dan karakteristiknya. Potensi yang dapat di kembangkan di lahan kering adalah sebagai pertanian, perkebunan, peternakan, dan kehutanan dengan tujuan meningkatkan produksi tanaman dan hasil perkebunan. Salah satu yang sudah di kembangkan oleh pemerintah adalah pertanian lahan kering.

Pertanian lahan kering adalah lahan dengan kebutuhan air untuk tanaman tergantung sepenuhnya oleh air hujan dan tidak pernah tergenang air secara tetap. Musim tanam pada pertanian lahan kering didasarkan atas keadaan musim dalam setahun. Periode tanam pada pertanian lahan kering ditentukan oleh awal mulai hujan turun. Panjang periode tanam biasanya ditentukan berdasarkan data iklim rangkai waktu paling tidak selama 20 tahun yang kemudian diekstrapolasi dan dianalisis guna menentukan tanggal awal dan tanggal akhir untuk suatu kawasan (Benu, 2013: 14-19).

Salah satu wilayah di Pulau Jawa yang memiliki pertanian lahan kering adalah di wilayah Kabupaten Blitar. Luas pertanian lahan kering berbasis tegalan di Kabupaten Blitar kurang lebih 127.154 Ha dan luas lahan basah 31.725 Ha pada tahun 2010 (BPS Kabupaten Blitar, 2011). Kabupaten Blitar merupakan salah satu wilayah di Provinsi Jawa Timur bagian selatan, secara astronomis terletak di $111^{\circ} 25^{\prime}-112^{\circ} 20^{\prime} B T$ dan $7^{0} 57^{\prime}-89^{\circ} 51^{\prime} \mathrm{LS}$. Secara administrasi berbatasan dengan Kabupaten Kediri di sebelah utara dan Kabupaten Malang di sebelah timur, Samudera Hindia di sebelah selatan, serta Kabupaten Tulungagung dan Kabupaten Kediri di sebelah barat. 
Dari beberapa kecamatan di wilayah Kabupaten Blitar, Kecamatan Binangun merupakan salah satu kecamatan yang memanfaatkan potensi lahan kering untuk pertanian. Menurut data BPS tahun 2014, kecamatan ini memiliki luas lahan kering sebesar $7.557 \mathrm{Ha}$ dibandingkan dengan luas lahan basah yang hanya $122 \mathrm{Ha}$. Wilayah di Kecamatan Binangun yang memanfaatkan lahan kering untuk pertanian cabai rawit adalah di Desa Sumber Kembar dan Desa Salamrejo. Diduga kedua daerah ini memiliki kondisi fisik yang hampir sama untuk usaha tani cabai rawit sehingga sebagian besar petani di kedua daerah tersebut memanfaatkan tanaman cabai rawit untuk pertanian lahan kering.

Kenyataannya dalam mengelola usaha tani cabai rawit pada lahan kering, petani di kedua daerah tersebut sering mendapatkan permasalahan-permasalahan sehingga berpengaruh terhadap produktivitas usaha tani cabai rawit. Permasalahan yang ada diantaranya, kondisi fisik diduga kurang sesuai dengan syarat tumbuh tanaman cabai rawit sebab wilayah penelitian berada di ketinggian $\pm 120-450$ mdpl. Rata-rata curah hujan tahunan $15 \mathrm{~mm} /$ thn dengan rata-rata hari hujan 53 hari/thn, keterbatasan air sebab pertanian di kedua daerah penelitian hanya mengandalkan air hujan, wilayahnya berada di pegunungan, kemiringan lereng wilayah mencapai $30 \%$.

Usaha tani cabai rawit memerlukan modal yang cukup besar, keterbatasan modal yang di miliki oleh petani dalam mengembangkan usaha tani cabai rawit, terutama modal untuk pembelian plastik penutup, pupuk dan obat-obatan yang harganya relatif naik setiap kali masa tanam tiba. Hal ini mendorong petani harus mencari pinjaman untuk mendapatkan modal. Besarnya biaya produksi yang dikeluarkan petani untuk usaha tani cabai rawit terkadang kurang sebanding dengan besar produktivitas bersih yang diterima selama satu kali musim panen. Menurut Dinas Pertanian Kabupaten Blitar Tahun 2013 menunjukkan bahwa produksi usaha tani cabai rawit tidak stabil selama tiga tahun belakangan, bahkan mengalami penurunan.

Tabel.1. Produksi Usaha Tani Cabai Rawit di Kecamatan Binangun tahun 2011-2013

\begin{tabular}{|l|l|l|l|}
\hline Tahun & Luas Tanam & Luas Panen & Produksi (ton) \\
\hline 2011 & 2.300 ha & 620 ha & 8.950 \\
\hline 2012 & 1.450 ha & 688 ha & 2.820 \\
\hline 2013 & 1.400 ha & 185 ha & 3.094 \\
\hline
\end{tabular}

Sumber: Dinas Pertanian Kabupaten Blitar Tahun 2013

Selama tiga tahun belakangan produktivitas usaha tani cabai rawit tidak stabil. Ketidak srabilan produktivitas tanaman cabai dikarenakan beberapa faktor diantaranya, sebagian besar petani mengalami kegagalan panen akibat cuaca yang ekstrim, serangan hama porong. Sistem pengelolaan usaha tani cabai rawit yang tergolong masih tradisional. Pupuk dan obat-obatan yang digunakan untuk memberantas hama dan penyakit menggunakan bahan kimia tetapi kurang maksimal. Pengetahuan petani lahan kering yang masih rendah terkait upaya meningkatkan produksi usaha tani cabai rawit. Jarang sekali di adakan penyuluhan dari dinas pertanian. Disamping itu juga terdapat permainan harga antara tengkulak dan pedagang sehingga harga yang di berikan kepada petani tidak menentu, relatif rendah dan mengakibatkan kerugian. Faktor aksesibilitas juga 
mempengaruhi usaha tani cabai rawit sebab aksesibilitas di wilayah Desa Salamrejo dan Desa Sumber Kembar tergolong sangat sulit karena kondisi jalan yang rusak parah akibat truk-truk pengangkut dengan muatan yang berat, jarak yang cukup jauh dari pusat kota, merupakan daerah pegunungan.

\section{METODE}

Penelitian ini merupakan penelitian deskriptif kuantitatif, penelitian yang berusaha menggungkapkan fakta-fakta menggunakan angka-angka dalam penyajiannya. Lokasi penelitian yang pilih adalah di Desa Sumber Kembar dan Desa Salamrejo Kecamatan Binangun Kabupaten Blitar yang notabennya merupakan daerah yang memanfaatkan lahan kering untuk pertanian cabai rawit. Penelitian ini lebih cenderung menggunakan pendekatan keruangan, sebab membandingkan dua wilayah atau ruang yang memiliki perbedaan ruang yang cukup mencolok.

Variabel penelitian meliputi faktor fisik, faktor non fisik yang mempengaruhi usaha tani cabai rawit, pengelolaan usaha tani cabai rawit, hambatan dan solusi usaha tani cabai rawit, perbedaan produktivitas bersih, hubungan antara biaya produksi dan produktivitas bersih. Populasi penelitian meliputi populasi fisik semua lahan kering yang dimanfaatkan untuk usaha tani cabai rawit di Kecamatan Binangun.

Populasi dalam dalam penelitian terbagi menjadi dua yaitu, populasi non fisik meliputi semua lahan kering yang dimanfaatkan untuk usaha tani cabai rawit di Kecamatan Binangun, dan populasi non fisik sejumlah 1.283 Kepala Rumah Tangga (KRT) Petani. Sampel penelitian berjumlah 93 KRT petani yang terbagi menjadi dua yaitu 60 KRT petani di Desa Sumber Kembar dan 33 KRT petani di Desa Salamrejo. Teknik pengumpulan data dengan wawancara, observasi, dan dokumentasi. Analisis penelitian deskriptif kuantitatif, yatu penyajian hasil pengolahan data dalam bentuk tabel frekuensi dan tabel silang, untuk mencari hubungan menggunakan uji korelasi product moment.

\section{HASIL DAN PEMBAHASAN}

\section{Kesesuaian Faktor Fisik dengan Syarat Tumbuh Tanaman Cabai Rawit}

Faktor fisik berperan penting dalam kegiatan usaha tani. Faktor fisik yang mempengaruhi usaha tani diantaranya ketinggian tempat, topografi, jenis tanah, $\mathrm{pH}$ tanah, curah hujan, temperatur (Tjakrawiralaksana dan Soeriaatmadja, 1983). Tingkat kesesuaian faktor fisik dengan syarat tumbuh tanaman cabai rawit bervariasi di kedua desa (Tabel 2).

Faktor fisik di Desa Sumber Kembar kurang sesuai untuk usaha tani cabai rawit. Hal ini ditunjukkan oleh terdapatnya lima syarat tumbuh cabai rawit yang tidak sesuai seperti curah hujan, topografi, temperatur, pH tanah, dan ketersediaan air. Adapun faktor fisik di Desa Salamrejo sesuai untuk usaha tani cabai rawit. Indicator kesesuaian tersebut adalah empat syarat tumbuh cabai rawit dengan yang sesuai dengan faktor fisik di Desa Salamrejo antara lain ketinggian tempat, temperatur, jenis tanah, $\mathrm{pH}$ tanah.

Terdapat dua faktor pembatas yang mempengaruhi tingkat kesesuaian faktor fisik untuk usaha tani di Desa Sumber Kembar dan Desa Salamrejo yaitu faktor pembatas permanen dan non permanen. Faktor pembatas permanen meliputi curah hujan dan 
temperatur. Faktor pembatas non permanen di kedua antara lain topografi dan ketersediaan air. $\mathrm{pH}$ tanah merupakan faktor pembatas khusus untuk yang dijumpai di Desa Sumber Kembar.

Tabel 2. Tingkat kesesuaian faktor fisik di Desa Sumber Kembar dan Salamrejo dengan syarat tumbuh tanaman cabai rawit

\begin{tabular}{|c|c|c|c|c|c|}
\hline \multirow[t]{2}{*}{$\mathrm{No}$} & \multirow{2}{*}{$\begin{array}{l}\text { Syarat Tumbuh Cabai } \\
\text { Rawit }\end{array}$} & \multicolumn{2}{|c|}{ Kondisi Fisik } & \multicolumn{2}{|c|}{ Tingkat Kesesuaian } \\
\hline & & $\begin{array}{l}\text { Sumber } \\
\text { kembar }\end{array}$ & Salamrejo & $\begin{array}{l}\text { Sumber } \\
\text { kembar }\end{array}$ & Salamrejo \\
\hline \multirow{5}{*}{1} & \multicolumn{5}{|l|}{ Iklim } \\
\hline & $\begin{array}{l}\text { Curah hujan } \\
600-1.200 \mathrm{~mm} / \text { tahun }\end{array}$ & $\begin{array}{l}2.400 \\
\mathrm{~mm} / \text { tahun }\end{array}$ & $\begin{array}{l}2.400 \\
\mathrm{~mm} / \text { tahun }\end{array}$ & $\begin{array}{l}\text { Tidak } \\
\text { sesuai }\end{array}$ & $\begin{array}{l}\text { Tidak } \\
\text { sesuai }\end{array}$ \\
\hline & $\begin{array}{l}\text { Ketinggian Tempat } \\
0-500 \mathrm{mdpal}\end{array}$ & 310 mdpl & 300 mdpl & Sesuai & Sesuai \\
\hline & $\begin{array}{l}\text { Topografi } \\
<30 \%\end{array}$ & $33,3 \%$ & $33,3 \%$ & $\begin{array}{l}\text { Tidak } \\
\text { sesuai }\end{array}$ & $\begin{array}{l}\text { Tidak } \\
\text { sesuai }\end{array}$ \\
\hline & $\begin{array}{l}\text { Temperatur } \\
18-30^{\circ} \mathrm{C}\end{array}$ & $32^{\circ} \mathrm{C}$ & $28^{\circ} \mathrm{C}$ & $\begin{array}{l}\text { Tidak } \\
\text { sesuai }\end{array}$ & Sesuai \\
\hline \multirow{3}{*}{2} & \multicolumn{5}{|l|}{ Kondisi Tanah } \\
\hline & $\begin{array}{l}\text { Jenis Tanah } \\
\text { mediteran, alluvial }\end{array}$ & $\begin{array}{l}\text { Mediteran } \\
\text { merah }\end{array}$ & $\begin{array}{l}\text { Mediteran } \\
\text { cokelat } \\
\text { kemerahan }\end{array}$ & Sesuai & Sesuai \\
\hline & $\begin{array}{l}\mathrm{pH} \text { tanah } \\
6,0-7,0\end{array}$ & 4,0 & 6,0 & $\begin{array}{l}\text { Tidak } \\
\text { Sesuai }\end{array}$ & Sesuai \\
\hline 3 & $\begin{array}{l}\text { Ketersediaan air } \\
\text { banyak }\end{array}$ & Sedikit & Sedikit & $\begin{array}{l}\text { Tidak } \\
\text { sesuai }\end{array}$ & $\begin{array}{l}\text { Tidak } \\
\text { sesuai }\end{array}$ \\
\hline
\end{tabular}

\section{Faktor Non Fisik yang Mempengaruhi Usaha Tani Cabai Rawit pada Pertanian Lahan Kering}

Terdapat dua faktor non fisik yang mempengaruhi usaha tani cabai rawit pada pertanian lahan kering di Desa Sumber Kembar dan Desa Salamrejo yaitu modal dan tenaga kerja. Dalam kaitannya dengan modal terdapat beberapa hal yang bervariasi yaitu lama usaha tani, besar dan asal modal yang dikeluarkan petani, serta luas dan status kepemilikan lahan. Lama usaha tani bervariasi antara 1 - 10 tahun hingga 41 - 50 tahun. Berdasarkan wawancara yang dilakukan kepada responden di Desa Sumber Kembar dan Salamrejo diketahui bahwa sebagian besar lama usaha tani cabai rawit adalah 1 - 10 tahun yaitu sebesar 33\% di Desa Sumber Kembar dan 30\% di Desa Salamrejo. Lama usaha tani ditunjukkan oleh Tabel 3.

Besarnya modal yang dikeluarkan oleh petani juga bervariasi baik di Desa Sumber Kembar maupun Salamrejo. Petani di Desa Sumber Kembar paling besar mengeluarkan modal kurang dari Rp 1.964.000, sedangkan petani di Desa Salamrejo paling banyak mengeluarkan modal Rp 1.964.001- Rp 3.928.000. Rata-rata modal di Desa Sumber Kembar yaitu Rp.4.189.917.000 dan rata-rata di Desa Salamrejo Rp.5.730.303. Perbedaan besar modal dan rata-rata modal yang dikeluarkan petani di desa Salamrejo dan Sumber Kembar 
berhubungan dengan skala usaha cabai rawit. Besarnya modal yang dikeluarkan oleh petani untuk usaha tani cabai rawit ditunjukkan oleh Tabel 4.

Tabel 3. Lama Usaha Tani Cabai Rawit di Desa Sumber Kembar dan Salamrejo

\begin{tabular}{|c|c|c|c|c|c|}
\hline \multirow{2}{*}{ No } & \multirow{2}{*}{ Lama Usaha (Tahun) } & \multicolumn{4}{|c|}{ Desa } \\
\cline { 3 - 6 } & & \multicolumn{2}{|c|}{ Sumber Kembar } & \multicolumn{2}{c|}{ Salamrejo } \\
\cline { 3 - 6 } & & $\boldsymbol{f}$ & $\mathbf{\%}$ & $\boldsymbol{f}$ & $\mathbf{\%}$ \\
\hline 1 & $1-10$ & 20 & 33 & 10 & 30 \\
\hline 2 & $11-20$ & 17 & 28 & 9 & 27 \\
\hline 3 & $21-30$ & 15 & 25 & 7 & 21 \\
\hline 4 & $31-40$ & 2 & 10 & 6 & 18 \\
\hline 5 & $41-50$ & $\mathbf{6 0}$ & $\mathbf{1 0 0}$ & $\mathbf{3 3}$ & $\mathbf{1 0 0}$ \\
\hline & Jumlah & & & & \\
\hline
\end{tabular}

Sumber: Data Primer (2015)

Tabel 4. Besar Modal dalam Usaha Tani di Desa Sumber Kembar dan Salamrejo

\begin{tabular}{|c|c|c|c|c|c|}
\hline \multirow{2}{*}{ No } & \multirow{2}{*}{$\begin{array}{c}\text { Besar Modal } \\
(\text { Rp) }\end{array}$} & \multicolumn{4}{|c|}{ Desa } \\
\cline { 3 - 6 } & & \multicolumn{2}{|c|}{ Sumber Kembar } & \multicolumn{2}{c|}{ Salamrejo } \\
\cline { 3 - 6 } & & $\boldsymbol{F}$ & $\mathbf{\%}$ & $\boldsymbol{f}$ & $\mathbf{\%}$ \\
\hline 1 & 1.964 .004 .000 & 21 & 35 & 7 & 21 \\
\hline 2 & $3.928 .001-5.928 .000$ & 19 & 32 & 10 & 30 \\
\hline 3 & $5.892 .001-7.856 .000$ & 7 & 12 & 6 & 18 \\
\hline 4 & $7.856 .001-9.820 .000$ & 2 & 3 & 2 & 6 \\
\hline 5 & $9.820 .001-11.784 .000$ & 4 & 7 & 2 & 6 \\
\hline 6 & $11.784 .001-13.748 .000$ & 3 & 5 & 2 & 6 \\
\hline 7 & $13.748 .001-15.712 .000$ & 2 & 3 & 1 & 3 \\
\hline 8 & $15.712 .001-17.676 .000$ & - & - & 1 & 3 \\
\hline 9 & $\geq 17.676 .001$ & 1 & 2 & 2 & 6 \\
\hline 10 & Jumlah & $\mathbf{6 0}$ & $\mathbf{1 0 0}$ & $\mathbf{3 3}$ & $\mathbf{1 0 0}$ \\
\hline & & & & & \\
\hline
\end{tabular}

Sumber: Data Primer (2015)

Rata-rata modal yang diperoleh untuk petani di kedua Desa yakni berasal dari modal sendiri. Keputusan petani menggunkan modal pribadi atau sendiri untuk usaha tani cabai rawit karena enggan memperoleh resiko cukup besar untuk meminjam modal dari bank, sebab persyaratan yang diajukan oleh bank cukup rumit, bunga yang diberikan cukup tinggi sehingga memberatkan petani. Modal yang dipakai secara pribadi di peroleh dari tabungan hasil panen tahun sebelumnya dan hasil penjualan ternak, sehingga petani sedikit terhindar dari resiko yang cukup besar untuk mengusahakan usaha tani cabai rawit.

Luas lahan di kedua daerah penelitian paling banyak di dominasi lahan dengan luas $1.327 \mathrm{~m}^{2}$ dengan status lahan milik sendiri, dengan besar persentase $95 \%$ di Desa Sumber Kembar dan 94\% di Desa Salamrejo, alasan penggunaan lahan milik sendiri untuk memaksimalkan keuntungan dari usaha tani cabai rawit. 
Petani di kedua daerah penelitian rata-rata cenderung menggunakan tenaga upah untuk keperluan pengolahan lahan hingga proses panen cabai rawit. Hampir 63 \% petani di Desa Sumber Kembar menggunakan tenaga upah, hal yang sama juga dijumpai pada petani di Desa Salamrejo yaitu sekitar 54\% juga menggunakan tenaga upah. Alasan kedua petani di daerah penelitian menggunakan tenaga upah adalah untuk menghemat tenaga dan waktu. Biaya rata-rata yang dikeluarkan untuk tenaga upah di Desa Sumber Kembar dan Desa Salamrejo kurang lebih sebesar Rp. 1.820.000, disesuaikan dengan jumlah tenaga kerja yang dibutuhkan.

Alat transportasi sangat membantu petani menuju lahan pertanian untuk mempersingkat waktu. Petani di kedua desa sebagian besar mengunakan sepeda motor untuk menuju lahan pertanian yaitu sebesar 61\% di Desa Sumber Kembar dan 76\% di Desa Salamrejo. Penggunaan sepeda motor oleh petani dimaksudkan agar dapat lebih menghemat waktu. Selain itu petani dapat membawa barang dengan beban yang cukup berat seperti pupuk dan makanan ternak. Sepeda Motor juga merupakan alat transportasi yang digunakan untuk mengangkut hasil panen di kedua desa. Selain sepeda motor terdapat pula petani yang berjalan kaki dengan persentase sebesar 37\% di Desa Sumber Kembar dan 21\% di Desa Salamrejo. Petani yang menggunakan sepeda hanya 2\% di Desa Sumber Kembar dan 3\% di Desa Salamrejo. Dengan menggunakan kendaraan bermotor untuk mengangkut hasil panen menuju tempat penjualan, petani mengeluarkan biaya tambahan. Biaya yang dikeluarkan dalam satu kali musim panen umumnya antara $40.001-$ 80.000, yaitu sebesar 70\% di Desa Sumber Kembar dan 76\% di Desa Salamrejo. Petani yang mengeluarkan biaya $\leq 40.000$ sebanyak $22 \%$ di Desa Sumber Kembar dan 21\% di Desa Salamrejo. Pengeluaran biaya transportasi sebesar 80.001 - 120.000 dan $120.001-160.000$ hanya dijumpai di Desa Sumber Kembar yaitu masing-masing 7\% dan 2\%. Pengeluaran tertinggi sebesar 160.001 - 200.000 hanya dijumpai di Desa Salamrejo yaitu sebesar 3\%.

Selain alat transportasi yang diperlukan dalam pengangkutan sarana usahatani dan hasil pertanian, teknologi juga sangat penting berkaitan dengan bagaimana cara melakukan usahatani untuk mendapatkan produktivitas yang lebih baik (Banowati dan Sriyanto. 2013) Pengolahan lahan untuk usaha tani cabai rawit dapat dilakukan dengan alat tradisional (cangkul, ganco), modern (traktor), maupun campuran (traktor, cangkul, ganco), namun $85 \%$ petani di kedua daerah penelitian memilih menggunakan alat tradisional untuk pengolahan lahan karena menurut petani alat tradisional tidak membutuhkan biaya perawatan dan sewa yang mahal. Alat-alat pertanian yang diperoleh petani di kedua desa diperoleh secara campuran, yaitu ada alat yang dibuat sendiri seperti luju (alat untuk menanam cabai) dan ada alat pertanian yang diperoleh dari membeli yaitu cangkul, wangkil, ganco, dan alat penyemprot obat.

Dalam mengembangkan usaha tani cabai rawit pada pertanian lahan kering, petani memperoleh pengetahuan dari petani lain, penyuluhan, orang tua, dan campuran. Ratarata petani di kedua daerah penelitian memperoleh pengetahuan usaha tani cabai rawit berasal dari petani lain dengan persentase untuk Desa Sumber Kembar 57\%, dan Desa Salamrejo 52\%. Hal ini terjadi karena pengetahuan yang berasal dari petani lain lebih mudah diperoleh dan efektif karena berdasarkan pengalaman. 
Kelompok tani memiliki fungsi, diantaranya mewadahi antar petani dalam bertukar pikiran, memberikan bantuan simpan pinjam, memberikan kemudahan petani memperoleh pupuk, pestisida untuk tanaman. Di Desa Sumber Kembar terdapat tiga unit kelompok tani yang masih aktif, sedangkan di Desa Salamrejo terdapat empat kelompok tani namun hanya dua kelompok tani yang masih aktif. Kelompok tani yang tidak aktif di sebabkan karena tidak adanya generasi penerus, kurangnya perhatian petani terhadap kondisi kelompok tani, masih berlakunya sistem nepotisme, kurangnya kerja sama antara pengurus dan anggota. Keterlibatan petani di dalam kelompok tani tergolong cukup memprihatikan. 70\% petani di Desa Sumber Kembar memilih tidak menjadi anggota kelompok tani dengan alasan sistem pengrekrutan anggota kelompok tani dibatasi atau berkuota dan masih bersifat kekeluargaan dalam arti petani dapat masuk menjadi anggota kelompok tani apabila salah satu saudara menjadi pengurus, hal ini juga dirasakan oleh petani cabai rawit di Desa Salamrejo yang 73\% juga memilih tidak ikut menjadi anggota kelompok tani.

Penyuluhan pertanian di Desa Sumber Kembar (58\%) dan Desa Salamrejo (64\%) dilakukan setiap 2 bulan sekali untuk menghindari kejenuhan petani dalam mengikuti penyuluhan. Namun sangat disayangkan keterlibatan petani sebagai peserta penyuluhan masih tergolong rendah. Hal ini ditunjukkan oleh besarnya persentase petani yang tidak ikut serta dalam penyuluhan yaitu sebesar 57\% untuk Desa Sumber Kembar dan 52\% untuk Desa Salamrejo. Banyaknya petani yang tidak ikut serta dalam penyuluhan disebabkan karena waktu penyelengaraan penyuluhan pertanian menganggu jam kerja petani diladang, yaitu sekitar pukul 10 hingga 11. Tempat penyelengaraan penyuluhan biasanya terpusat di balai desa dengan jarak yang cukup jauh dari tempat tinggal.

Dalam pengelolaan usaha tani cabai rawit pada pertanian lahan kering di Desa Sumber Kembar dan Desa Salamrejo terdapat beberapa tahap, yaitu pengolahan lahan, pembibitan, penanaman, dan pemeliharaan. Pengolahan lahan biasanya menggunakan system tumpang gilir, dimana tananam cabai ditanam bersamaan dengan pengolahan lahan untuk tanaman jagung dan kedelai. Waktu yang dibutuhkan untuk mengolah lahan di kedua desa sebagian besar 2-17 hari dengan persentase 67\% di Desa Sumber Kembar dan $52 \%$ di Desa Salamrejo. Perbedaan lama pengolahan lahan untuk usaha tani cabai rawit disebabkan karena luas lahan yang diolah, lahan pertanian yang terpecah atau tidak dalam satu lokasi, alat yang digunakan untuk mengolah lahan masih tradisional, jumlah tenaga kerja yang terbatas.

Dalam tahap pembibitan, bibit tanaman cabai rawit cukup mudah untuk dikembangkan atau dikecambahkan, sehingga petani dapat memperoleh bibit dari pembibitan sendiri, membeli, maupun bantuan dari pemerintah, namun $94 \%$ petani di Desa Sumber Kembar dan 88\% petani di Desa Salamrejo memperoleh bibit tanaman cabai rawit dari pembibitan sendiri dengan alasan petani dapat memantau kondisi bibit untuk meminimalisir bibit cabai yang rusak, menghemat biaya, serta dapat menentukan bibit yang layak dan baik untuk ditanam. Waktu yang dibutuhkan petani untuk melakukan pembibitan umumnya 27-39 hari, yaitu sebesar 80\% di Desa Sumber Kembar dan 82\% di Desa Salamrejo. Penerapan umur pembibitan cabai rawit sekitar 27-39 hari karena pada umur tersebut bibit cabai telah ideal untuk ditanam, kondisi akar sudah kuat, dan resiko tanaman 
mati relatif kecil. Penanaman cabai rawit menggunakan sistem tumpang sari. Alat yang digunakan untuk menanam cabai rawit yaitu luju. Penanaman biasanya dilakukan saat pertengahan bulan Desember sampai akhir Februari. Jarak tanam di Desa Sumber Kembar paling banyak 15-20 cm (55\%), sedangkan di Desa Salamrejo 26-30 cm (49\%). Perbedaan jarak tanam mempengaruhi pertumbuhan dan produksi tanaman cabai rawit. Jarak tanam yang diterapkan di Desa Salamrejo cukup jauh, dimaksudkan untuk memberikan ruang perkembangan akar, meratakan penerimaan cahaya matahari oleh tanaman cabai rawit.

Dalam pemeliharaan tanaman, Jenis pupuk yang yang paling banyak digunakan di Desa Sumber Kembar (33\%) dan di Desa Salamrejo (34\%) adalah pupuk Za, Ponska, dan organik. Pengunaan pupuk Za, Ponska, dan organic karena ketiga jenis pupuk tersebut umum digunakan petani yang memperoleh subsidi pupuk. Frekuensi pemupukan dilakukan secara berkala yaitu 3-5 kali dalam satu kali musim tanam. Rata-rata biaya yang dikeluarkan petani untuk pemupukan untuk petani di Desa Sumber Kembar (62\%) kurang dari Rp. 1.298.000, sedangkan petani di Desa Salamrejo terbagi menjadi 2 yakni, 30\% untuk petani yang mengeluarkan biaya pemupukan kurang dari Rp. 1.298.000, dan 30\% kedua untuk petani yang mengeluarkan biaya pemupukan antara Rp. 1.298.000 - Rp 2.596.000. Ratarata biaya pemupukan yang dikeluarkan petani di kedua desa adalah Rp 1.396 .767 untuk Desa Sumber Kembar dan Rp 3.125.455 untuk Desa Salamrejo. Secara keseluruhan biaya pemupukan di kedua daerah penelitian masih tergolong rendah karena dosis yang digunakan kurang sesuai dengan kebutuhan tanaman. Selain itu, petani di kedua daerah penelitian memiliki cara yang unik untuk menghindari harga pupuk yang dari setiap musim tanam meningkat yaitu dengan melakukan pemimbunan pupuk. Sistem pengairan yang digunakan petani di kedua desa berasal dari air hujan karena tidak terdapat saluran irigasi dan hanya mengandalkan air hujan untuk pengairan. Frekuensi pengairan disesuaikan atau tergantung oleh kejadian hujan.

Metode penyiangan di kedua daerah penelitian sedikit berbeda, $62 \%$ petani di Desa Sumber Kembar menggunakan metode penyiangan secara modern, sedangkan $67 \%$ petani di Desa Salamrejo menggunakan metode penyiangan campuran. Pemilihan metode penyiangan campuran untuk menghindari kerusakan tanaman dan menghindari penyusutan kandungan organik dalam tanah. Pendangiran di daerah penelitian dilakukan sedikit berbeda tergantung cara penyiaangan. Ketika petani menggunakan penyiangan secara modern maka pendangiran harus menunggu 1 minggu sebab menunggu kandungan bahan kimia menghilang. Berbeda dengan penyiangan menggunakan cara mekanik maka pendangiran dapat dilakukan secara bersamaan.

Hama dan penyakit yang paling banyak menyerang tanaman cabai rawit di Desa Sumber Kembar (27\%) dan di Desa Salamrejo (22\%) adalah hama porong. Serangan hama porong terjadi karena gangguan cuaca. Cara memberantas hama porong $100 \%$ menggunakan penyemprotan herbisida. Petani di Ds.Sumber Kembar sebagian besar (43\%) mengeluarkan biaya obat Rp. 86.401-172.800, sedangkan di Desa Salamrejo (42\%) mengeluarkan Rp. 172.801-259.200. Data tersebut memperlihatkan Desa Salamrejo lebih banyak menggunakan obat-obatan untuk memberantas hama dan penyakit. 
Tanaman cabai rawit siap dipanen setelah berusia antara 3,5 hingga 4 bulan. Frekuensi pemetikan dalam satu bulan responden di Desa Sumber Kembar (97\%) dan di Desa Salamrejo (85\%) sebanyak 4 kali, karena menyesuaikan tingkat kematangan buah cabai dan permintaan pasar. Waktu pemetikan responden di Desa Sumber Kembar (43\%) dilakukan pada pagi hari karena menghindari sinar matahari yang dapat merusak buah cabai, berbeda dengan responden di Desa Salamrejo yang melakukan pemetikan pada pagi, siang, dan sore (55\%), karena mengejar harga pasar dan mempercepat proses pemetikan. Pemasaran cabai rawit dijual kepada tengkulak oleh petani Desa Sumber Kembar (82\%) dan petani Desa Salamrejo (97\%), karena tengkulak langsung mendatangi petani ke lahan pertanian. Wilayah pendistribusian hasil panen cabai rawit paling besar adalah di luar provinsi yaitu Jakarta, Kalimantan, Sumatera, dan Bali.

\section{Hambatan dan Solusi dalam Usaha Tani Cabai Rawit}

Terdapat tiga hambatan yang dihadapi oleh petani di Desa Sumber Kembar dan Desa Salamrejo yaitu hambatan yang berasal dari kondisi fisik, hambatan yang berasal dari non fisik dan hambatan yang berasal dari pengelolaan usaha tani. Hambatan fisik berupa hambatan campuran yaitu perpaduan dari iklim, topografi, kondisi tanah, dan ketersediaan air. Hambatan fisik yang kompleks terjadi karena wilayah ini berada di daerah pegunungan sehingga sumber mata air yang digunakan untuk mengairi pertanian terbatas dan tanah kurang subur. Solusi untuk mengatasi yaitu membuat bedengan penganti teras iring, pemberian pupuk kandang, pengolahan lahan menggunakan cara tradisional, dan pengistirahatan lahan untuk beberapa bulan.

Hambatan non fisik yang paling dihadapi adalah kekurangan modal. Petani sebagian besar mengalami hambatan berupa kekurangan modal, karena enggan mengambil resiko yang cukup tinggi untuk meminjam ke bank, sehingga menggunakan modal seadanya. Solusi untuk mengatasinya meminjam modal kepada keluarga, menyimpan sisa hasil panen berupa uang maupun barang untuk dijadikan modal cadangan. Hambatan pengelolaan yang dihadapi oleh petani adalah serangan dan gangguan hama penyakit. Solusi yang telah dilakukan oleh petani adalah pemberian pestisida dengan frekuensi maksimal 4 kali dalam satu kali musim tanam.

\section{Perbedaan Produktivitas Usaha Tani Cabai Rawit}

Rata-rata produksi cabai rawit dalam satu kali musim panen di Desa Sumber Kembar adalah $1.247,65 \mathrm{~kg}$ sedangkan di Desa Salamrejo adalah 2.819,03 kg. Perbedaan besar produksi cabai rawit ini dipengaruhi oleh jarak tanam yang terlalu dekat, gangguan cuaca, pola pemeliharaan yang kurang tepat, dan ketersediaan air di daerah penelitian tergolong sedikit dan hanya mengandalkan curah hujan.

Rata-rata produktivitas kotor yang diterima petani di Desa Sumber Kembar dan Desa Salamrejo berbeda. Rata-rata produktivitas kotor di Desa Sumber Kembar adalah Rp. 7.547.117, sedangkan di Desa Salamrejo Rp. 16.180.879. Perbedaan ini dipengaruhi oleh produksi cabai di Desa Sumber Kembar lebih sedikit dibandingkan dengan produksi cabai rawit di Desa Salamrejo. Selain itu rata-rata harga jual yang ditetapkan oleh tengkulak 
kepada petani cukup rendah dan pengaruh dari kondisi fisik yang kurang sesuai terutama di Desa Sumber Kembar.

Rata-rata total biaya produksi yang dikeluarkan petani di Desa Sumber Kembar adalah Rp. 1.596.810, sedangkan Desa Salamrejo Rp.1.593.553. Selisih biaya yang dikeluarkan sedikit, hal ini karena petani di kedua desa sama-sama mengeluarkan biaya untuk pupuk, obat, dan tenaga kerja, tetapi petani di Desa Sumber Kembar lebih banyak menggeluarkan biaya untuk tenaga kerja sehingga rata-rata yang di keluarkan lebih banyak di bandingkan dengan rata-rata biaya yang di keluarkan petani di Desa Salamrejo.

Rata-rata produktivitas bersih per $1000 \mathrm{~m}^{2}$ dalam satu kali musim panen adalah Rp.3.923.859 di Desa Sumber Kembar dan Rp 15.913.815 di Desa Salamrejo. Hal yang menyebabkan perbedaan cukup besar pada rata-rata produktivitas bersih di Desa Salamrejo dan Desa Sumber Kembar yaitu adanya perbedaan perlakuan seperti penerapan jarak tanam, kondisi fisik di Desa Salamrejo sesuai untuk usaha tani cabai rawit dibandingkan dengan kondisi fisik di Desa Sumber Kembar yang kurang sesuai, sistem pemeliharaan terutama pemberian pupuk dan pemberantasan hama dan penyakit.

\section{Hubungan Antara Biaya Produksi Dengan Produktivitas Bersih Usaha Tani Cabai Rawit}

Terdapat hubungan antara biaya produksi dengan produktivitas bersih. Pada dasarnya apabila biaya produksi rendah maka produktivitas bersih yang diperoleh tinggi. Hasil analisis korelasi antara biaya produksi dengan Produktivitas Bersih di Desa Sumber Kembar ditunjukkan oleh Tabel 5, sedangkan untuk Desa Salamrejo ditunjukkan oleh Tabel 6. Hubungan biaya produksi dengan produktivitas bersih di Ds.Sumber Kembar adalah hubungan positif tetapi lemah karena nilai koefisien 0,210. Terdapat perbedaan biaya produksi yang dikeluarkan tidak sesuai dengan produktivitas bersih yang diterima. Hubungan biaya produksi dengan produktivitas bersih di Ds. Salamrejo adalah hubungan negative linier sempurna karena nilai koefisien menunjukkan angka $-0,197$, petani cenderung melakukan pengelolaan secara tradisional, peningkatan biaya produksi sehingga terjadi perbedaan besar produktivitas bersih yang diterima, kondisi fisik di Desa Salamrejo yang cukup sesuai untuk usaha tani cabai rawit.

Tabel 5. Korelasi Biaya Produksi dengan Produktivitas Bersih di Desa Sumber Kembar dalam Satu Kali Musim Panen

Correlations

\begin{tabular}{|ll|c|c|}
\hline & & $\begin{array}{c}\text { Biaya } \\
\text { Produksi }\end{array}$ & $\begin{array}{c}\text { Produktivitas } \\
\text { Bersih }\end{array}$ \\
\hline Biaya Produksi & Pearson Correlation & 1 & .210 \\
Desa Sumber Kembar & Sig. (2-tailed) & & .107 \\
& $\mathrm{~N}$ & 60 & 60 \\
\hline Produktivitas Bersih & Pearson Correlation & .210 & 1 \\
Desa Sumber Kembar & Sig. (2-tailed) & .107 & 60 \\
\hline & $\mathrm{N}$ & 60 & \\
\hline
\end{tabular}


Tabel. 6. Korelasi Biaya Produksi dengan Produktivitas Bersih di Desa Salamrejo dalam Satu Kali Musim Panen

Correlations

\begin{tabular}{|ll|c|c|}
\hline & & $\begin{array}{c}\text { Biaya } \\
\text { Produksi }\end{array}$ & $\begin{array}{c}\text { Produktivitas } \\
\text { bersih }\end{array}$ \\
\hline Biaya Produksi & Pearson Correlation & 1 & -.197 \\
Desa Salamrejo & Sig. (2-tailed) & & .272 \\
& $\mathrm{~N}$ & 33 & 33 \\
\hline Produktivitas Bersih & Pearson Correlation & -.197 & 1 \\
Desa Salamrejo & Sig. (2-tailed) & .272 & \\
& $\mathrm{~N}$ & 33 & 33 \\
\hline
\end{tabular}

\section{SIMPULAN}

Dalam usaha tani cabai rawit pada pertanian lahan kering di Kecamatan Binangun Kabupaten Blitar terdapat berbagai kondisi yang bervariasi baik kondisi fisik maupun non fisik. Desa Salamrejo memiliki kondisi fisik yang sesuai sedangkan Desa Sumber Kembar tidak sesuai. Dalam penggunaan modal, tenaga kerja, dan penggunaan kendaraan bermotor terdapat perbedaan diantara kedua desa tersebut. Demikian pula hambatanhambatan yang dialami. Kondisi ini berpengaruh terhadap perbedaan produktivitas. Hal yang menyebabkan perbedaan tersebut adalah perbedaan perlakuan seperti penerapan jarak tanam, kondisi fisik di Desa Salamrejo sesuai untuk usaha tani cabai rawit dibandingkan dengan kondisi fisik di Desa Sumber Kembar yang kurang sesuai, serta sistem pemeliharaan terutama pemberian pupuk dan pemberantasan hama dan penyakit.

\section{UCAPAN TERIMA KASIH}

Penulis mengucapkan terima kasih kepada berbagai pihak yang telah membantu dalam pengambilan data dan analisis sehingga penelitian ini dapat terlaksana dengan baik.

\section{DAFTAR PUSTAKA}

Banowati, E., dan Sriyanto. 2013. Geografi Pertanian. Yogyakarta: Penerbit Ombak Benu, F.L. 2013. Revitalisasi Lahan Kering. Jakarta: JP II Publishing House BPS Kabupaten Blitar. 2011. Kabupaten Blitar dalam Angka 2011. Blitar: BPS

Suparmini., Sumunar, D.R.S., Widyastuti, M., Safitri, I., dan Pratiwi, D.O. 2015. Usahatani Hortikultura di Lereng Pegunungan, Studi Komparasi di Kecamatan Binangun Kabupaten Blitar dan Kecamatan Karangreja Kabupaten Purbalingga. Laporan Penelitian. LPPM UNY.

Tjakrawiralaksana, A. dan Soeriaatmadja, C. 1983. Usahatani. Jakarta: Depdikbud 